\title{
Assessment of Hygienic Quality of Beverage Cans Surfaces with and without Protective Cover
}

\author{
Gülten Tiryaki Gündüz ${ }^{1 *}$, Ayça Korkmaz ${ }^{2}$, İlkim Emenli ${ }^{3}$ Zeynep Öztürk ${ }^{4}$ \\ ${ }^{1 *}$ Food Engineering Department, Engineering Faculty, Ege University, 35040 İmir, Turkey \\ Corresponding author, E-mail: gulten.tiryaki.gunduz@ege.edu.tr, ORCID: https://orcid.org/0000-0002-5878-7411 \\ ${ }^{2}$ Food Engineering Department, Engineering Faculty, Ege University, 35040 Izmir, Turkey \\ E-mail: ayca.korkmaz1993@gmail.com, ORCID: https://orcid.org/0000-0003-2084-5337 \\ ${ }^{3}$ Food Engineering Department, Engineering Faculty, Ege University, 35040 İmir, Turkey \\ E-mail: ilkimemenli@gmail.com,ORCID: https://orcid.org/0000-0002-4557-6105 \\ ${ }^{4}$ Food Engineering Department, Engineering Faculty, Ege University, 35040 İzmir, Turkey \\ E-mail: ozturk.zeynep1993@gmail.com,ORCID: https://orcid.org/0000-0001-6002-7262
}

\begin{tabular}{|c|c|}
\hline A R T I C LE INFO & A B S T R A C T \\
\hline $\begin{array}{l}\text { Received : 10/06/2018 } \\
\text { Accepted : 22/11/0000 }\end{array}$ & $\begin{array}{l}\text { In this study, the microbial profiles of external top surfaces of beverage cans sold in Izmir } \\
\text { markets, and the survival of } E \text {. coli on the top surfaces of cans were investigated through the } \\
\text { storage period of } 0,10,20 \text { and } 30 \text { days at } 4 \text { and } 25^{\circ} \mathrm{C} \text {. Total aerobic mesophilic bacteria (TAMB), } \\
\text { coliforms and E.coli counts of } 100 \text { cans without protective cover and } 20 \text { cans with protective } \\
\text { cover were examined. The numbers of TAMB on the cans without protective cover were in the } \\
\text { range of } 0.43-2.20 \times 10^{3} \mathrm{cfu} / \mathrm{cm}^{2} \text {. Lower bacteria counts in the range of }<0.43-1.12 \times 10^{1} \mathrm{cfu} / \mathrm{cm}^{2} \\
\text { were observed on the cans with protective cover. E. coli was not detectable on the storage time of } \\
20 \text { days, whereas E. coli counts of higher than } 2 \log \text { units were observed at the } 10 \text { days of storage. } \\
\text { According to the results obtained from this study, the microbiological statuses of beverage cans } \\
\text { are not the same quality, external top surfaces of beverage cans might be a potential risk for } \\
\text { public health. }\end{array}$ \\
\hline
\end{tabular}

Hygienic status

Escherichia coli

Total aerobic mesophilic bacteria count

Coliform

Türk Tarım - Gıda Bilim ve Teknoloji Dergisi 7(1): 61-67, 2019

\section{Üzeri Koruyucu Ambalaj ile Kaplanmış ve Kaplanmamış Teneke Kutu İçecek Üst Yüzeylerinin Hijyenik Kalitesinin Değerlendirilmesi}

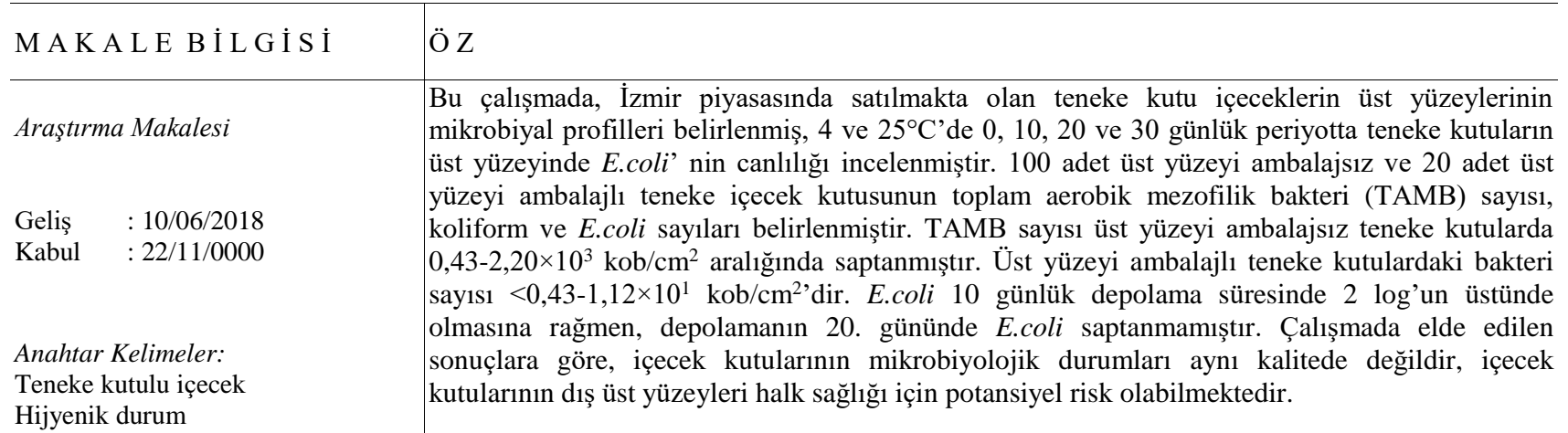

Escherichia coli

Toplam aerobik mezofilik bakteri

Koliform 


\section{Introduction}

Microbial attachment to surfaces is a potential way of transmission of pathogens in food processing industry, catering and the domestic environment (Kusumaningrum et al., 2003; Giauris and Nychas, 2006; Simoes et al., 2010; Kuda et al., 2015). Contaminations can be an intermediate step in transmission of pathogens from their original habitat in the environment to food contact surfaces (Reij et al., 2004; Silva and Martinis, 2013; Valero et al., 2017). Exposure of pathogens on surfaces may take place either by direct contact with contaminated objects or indirectly through airborne particles. Several studies indicated that various bacteria, including Escherichia coli, Staphylococcus aureus and Salmonella spp. survive on hands, sponges/cloths and utensils for hours or days after initial contact with the microorganisms (Scott and Bloomfield, 1990; Jiang and Doyle, 1999; Kusumaningrum et al., 2002; Kusumaningrum et al., 2003). Food stored under the sink or in locations where water, drain or heating pipes may pass; run an increased risk of pest invasion (Daniels, 1991; Michaels et al., 2003). Insects and rodents are common to these spaces, as they are difficult to seal and often contain moisture that is attractive to pests (Michaels et al., 2003). Cockroaches are known to carry Salmonella spp. and it is believed that they may represent reservoirs capable of spreading this organism to food products (Devi and Murray, 1991; Michaels et al., 2003). Dust on canned goods could also represent a potential infection hazard, as Salmonella spp. have been found viable in dust for up to 10 months (Michaels et al., 2003). Even though the cans are produced under hygienic conditions, they are exposed to some bacteria and germs during storage period, transportation and service. The risk of beverage cans to come in contact with rats, bugs, and other germs where they are stored is high (Ayçiçek and Küçükkaraarslan, 2003). Dirt accumulation of long-term storage, various abuse conditions described above, or even dripping of meat juices, is known to occur. Studies have reported that when food poisoning agents such as Salmonella Typhimurium and Staphylococcus aureus were dried and adhered onto stainless steel or glass surfaces in existence of nutrient rich food residue such as milk, meat and egg, they showed resistance to desiccation, surfactant disinfectant such as benzalkonium chloride, as well as 254-nm ultraviolet UV-C irradiation (Kuda et al., 2008; Kuda et al., 2011, Kuda et al., 2012; Li et al., 2014). This indicated that protein-, lipid-, and/or carbohydrate-rich food residue could preserve pathogens from stress conditions (Kuda et al., 2015). Because of these reasons, The Food and Drug Administration recommends washing all dirty canned goods with soap and water before opening. Even though the risks of having dirty beverage cans are quite different from food cans, there is a general abhorrence to drinking out of a can with a visibly dirty top, many people use a perfunctory to wipe of cans with paper products rather than rinsing or washing with soap and water (CFP 2000; US Navy, 2003; Michaels et al., 2003).

Chemical, physical and biological agents transmitted by food cause more than 200 recognized diseases in people (Kass and Riemann, 2006). Of these infectious biological agents are the most important causing the majority of foodborne diseases. Many of the infectious agents capable of causing foodborne diseases can be transmitted in ways other than via food or water. Agents transmitted by the fecal-oral route can cause infection through direct contact between hosts (Kass and Riemann, 2006). It was reported that, microorganisms present on the surface of beverage cans, which usually do not cause diseases directly, but might be opportunistic pathogens located in the tab area and contaminate the drink when the tab is opened, may cause serious diseases such as respiratory and urinary tract infections, and tuberculosis.

The aim of this study was to determine the contamination levels of external top surfaces of beverage cans with and without protective cover that are sold in the places such as supermarkets, grocery stores, restaurants and cafes; and also to investigate the survival of Escherichia coli inoculated to external top surfaces of beverage cans for 30 days.

\section{Materials and Methods}

\section{Sample Collection}

Commercially available beverage cans without any protective cover including ice tea (20), soda (20), beer (20), fruit juice (20), coke (20); and 20 cans (fruit juice and beer) with protective cover were randomly purchased, regardless of the brand and company names from supermarkets (41), grocery stores (38) and restaurants (21); 20 cans with protective cover in Izmir. Samples were taken the dates between 15.09.2015-15.02.2016 and analyzed within 24 hours after they were purchased.

Enumeration of Total Aerobic Mesophilic Bacteria, Coliforms and E.coli

Total aerobic mesophilic bacteria, coliform and E.coli counts were performed to determine the contamination levels of beverage cans. Swab samples were taken from the external top surfaces of beverage cans. Firstly, sterile swabs were wet with $0.1 \%$ sterile peptone water $(\mathrm{PW}, \mathrm{pH}$ 7-7.4, Merck) in the test tube by immersion and excess fluid on the swab was leaked by repression of cotton swab on the inner surface of the tube. After getting the samples from the external top surface of can by using the sterile swab, it was immersed in $10 \mathrm{ml}$ of sterile peptone water in the test tube and stirred about 30 seconds. Decimal dilutions were prepared and plated to Plate Count Agar (PCA, pH 6.8-7.2, Oxoid) plates. Inoculated petri dishes for total aerobic mesophilic bacteria count were incubated aerobically at $35 \pm 1^{\circ} \mathrm{C}$ for 48 hours (BAM, 2001). At the end of the incubation period, the colonies were counted and total viable counts were calculated as $\mathrm{cfu} / \mathrm{cm}^{2}$.

For total coliform bacteria count, $1 \mathrm{ml}$ inoculum was taken from appropriate dilutions applied to 3 set tubes which contain Durham tubes and $10 \mathrm{ml}$ Lauryl Sulphate Tryptose Broth (LSTB, pH 6.6-7.0, LabM). These tubes were incubated at $35 \pm 1^{\circ} \mathrm{C}$ for $24-48$ hours. After the incubation period, gas positive tubes were determined and the possible coliform bacteria count was determined. In order to prove the results of presumptive test, inoculation was applied by using sterile loop from all gas positive 
tubes to Brilliant Green Bile Broth (BGBB, pH 7.2-7.6, Oxoid) containing Durham tubes. At the end of the incubation period at $35 \pm 1^{\circ} \mathrm{C}$ for $24-48$ hours, gas positive tubes were determined and confirmed coliform bacteria count was calculated by using MPN table (BAM, 2002). For the determination of fecal coliforms and E.coli, a loopful of inoculum from gas positive tubes of LSTB was transferred to a tube of EC broth (EC, pH 6.9 \pm 0.2 , Oxoid). EC tubes were incubated at $44.5^{\circ} \mathrm{C}$ for $48 \pm 2 \mathrm{~h}$ and examined for gas production to calculate fecal coliform MPN. To continue with E. coli analysis, gas producing tubes of EC broth was streaked on a Eosin Methylene Blue Agar (EMB, pH 6.8 \pm 0.2 , Oxoid) plate and incubated for $18-24 \mathrm{~h}$ at $35^{\circ} \mathrm{C}$. Plates were examined for suspicious $E$. coli colonies and used for further testing (BAM, 2002).

\section{Survival of Escherichia coli on Beverage Cans}

Escherichia coli DSM 1103 culture was used as test culture. Stock cultures were grown in Tryptone Soya Broth (TSB, pH 7.3, Oxoid) and incubated at $37^{\circ} \mathrm{C}$ for 24 h. Appropriate dilutions were prepared from this culture, the dilutions of about $6.0-6.5 \mathrm{log} \mathrm{cfu} / \mathrm{ml}$ were prepared and the concentration applied was confirmed by using McFarland device and also by plating $0.1 \mathrm{ml}$ of appropriately diluted culture on Plate Count Agar (PCA, pH 6.8-7.2, Oxoid).

Before the inoculation of $E$. coli to the external top surfaces of cans, 21 beverage cans were firstly washed with water and then top surfaces were disinfected with $70 \%$ and $96 \%$ alcohol for 15 minutes, respectively. Bacterial suspension of $0.1 \mathrm{ml}$ (about 6.0-6.5 log $\mathrm{cfu} / \mathrm{ml}$ ) was spread on the disinfected surface of 21 beverage cans.
To determine the numbers of $E$. coli inoculated to the surface, 3 cans were analyzed just after the inoculation. The contaminated cans were incubated at $4{ }^{\circ} \mathrm{C}$ and $25^{\circ} \mathrm{C}$ for 10, 20 and 30 days. E. coli inoculation was applied on the top surfaces of 3 beverage cans for each time and temperature, and numbers of E. coli were determined after the incubation periods as described above.

\section{Statistical Analysis}

Statistical analysis were carried out using IBM SPSS Statistics 20. Kruskal Wallis Test was used to assess differences among beverage cans purchased from supermarkets, grocery stores, restaurants while KIndependent Sample $t$-test was used to assess differences among beverage cans with and without protective cover. Differences were considered significant at $\mathrm{P}<0.05$.

\section{Results and Discussion}

Total mesophilic aerobic bacteria count of external top surfaces of 100 beverage can samples without protective cover and total coliform bacteria count of 50 samples of these cans were analyzed to determine microbial profiles of external top surfaces of beverage cans sold in Izmir markets. The results of the analysis for the ice tea, soda, beer, fruit juice and coke samples without any protective cover taken from different places and different brands were given in Figures 1, 2, 3, 4 and 5, respectively. Considering the results of enumeration of total mesophilic aerobic bacteria of beverage cans without protective cover, it was observed that all the products were contaminated to varying degrees in the range of 0.43 $\mathrm{cfu} / \mathrm{cm}^{2}$ and $2.2 \times 10^{3} \mathrm{cfu} / \mathrm{cm}^{2}$.

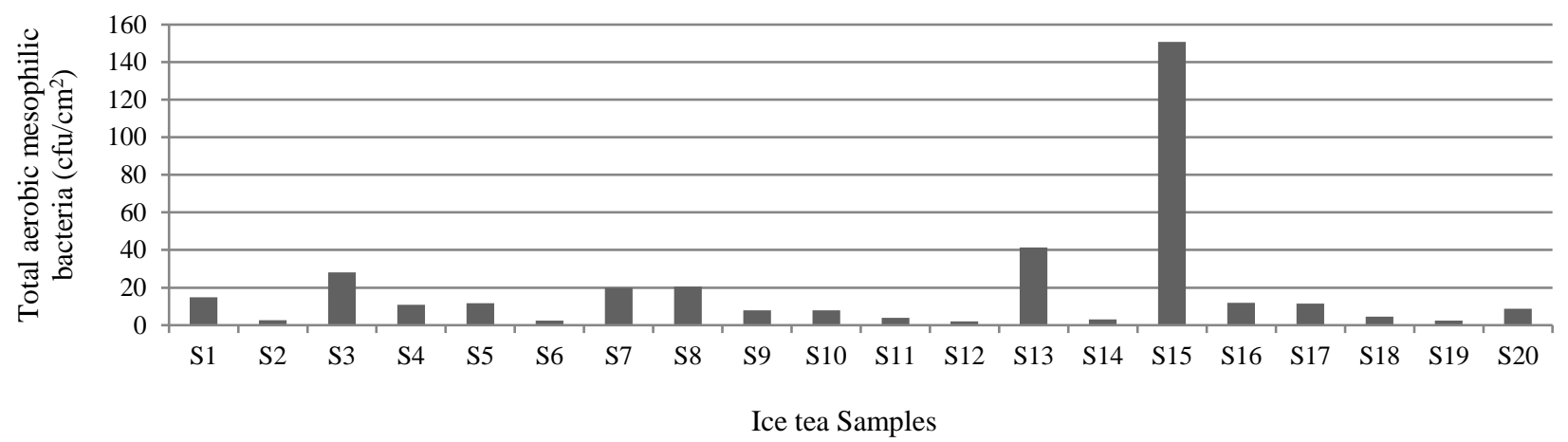

Figure 1 Total aerobic mesophilic bacteria counts of ice tea can top surfaces $\left(\mathrm{cfu} / \mathrm{cm}^{2}\right)$

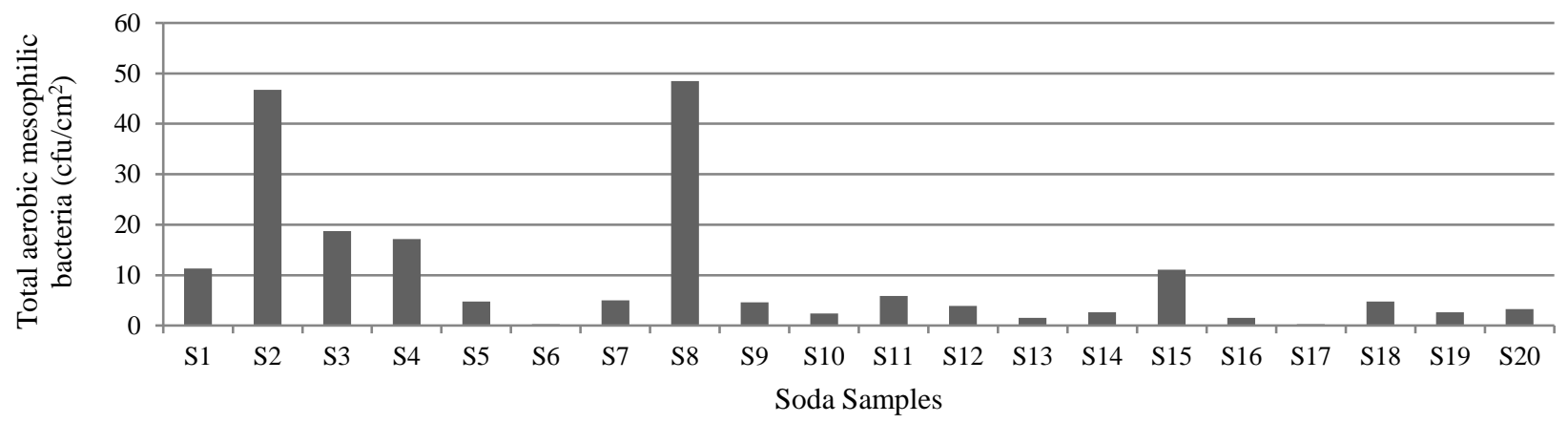

Figure 2 Total erobic mesophilic bacteria counts of soda can top surfaces $\left(\mathrm{cfu} / \mathrm{cm}^{2}\right)$ 


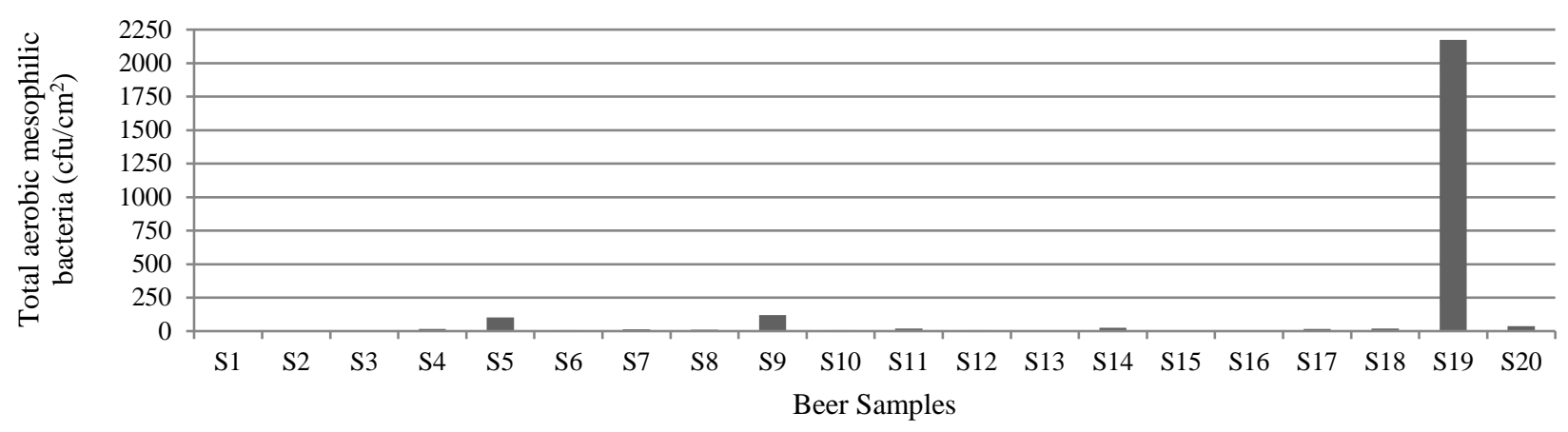

Figure 3 Total aerobic mesophilic bacteria counts of beer can top surfaces $\left(\mathrm{cfu} / \mathrm{cm}^{2}\right)$

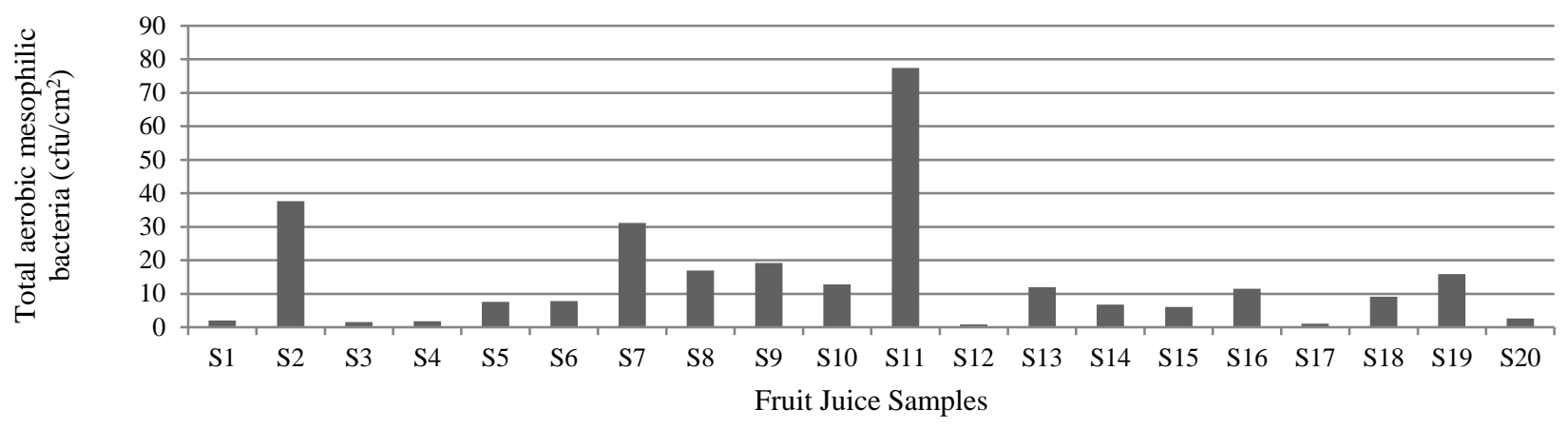

Figure 4 Total aerobic mesophilic bacteria counts of fruit juice can top surfaces $\left(\mathrm{cfu} / \mathrm{cm}^{2}\right)$

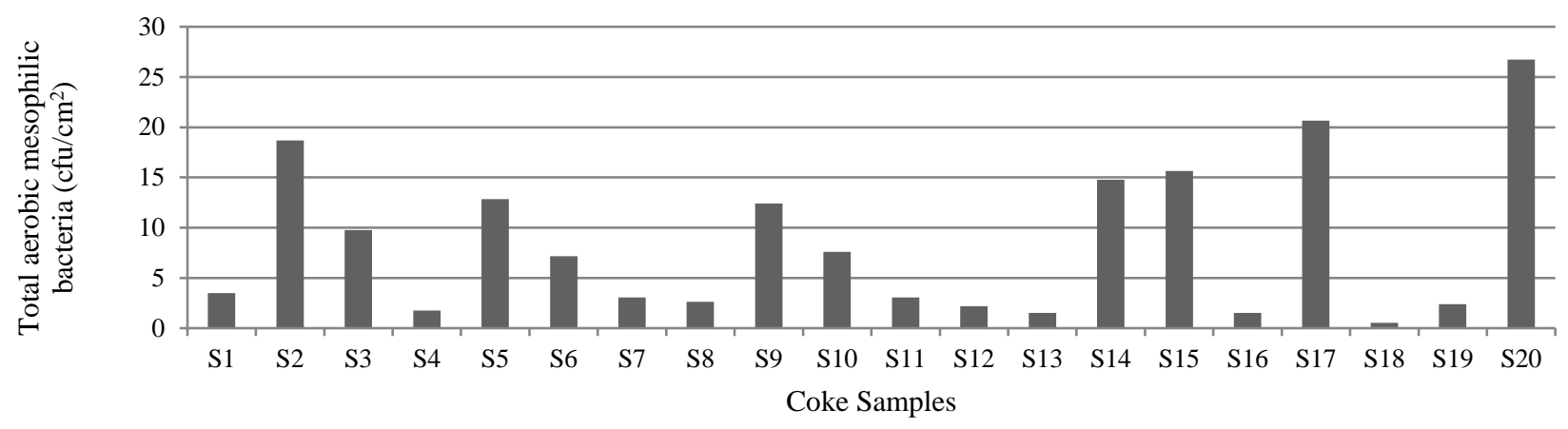

Figure 5 Total erobic mesophilic bacteria counts of coke can top surfaces $\left(\mathrm{cfu} / \mathrm{cm}^{2}\right)$

There are no microbiological criteria for the external surfaces of beverage cans or the surfaces with direct contact with the mouth. Dantas et al. (2006), used an acceptable level of contamination lower than $50 \mathrm{cfu} / \mathrm{cm}^{2}$ for total mesophilic aerobic microorganisms for hygienic cooking utensils. In another study, it is recommended that the satisfactory level of aerobic colony count is $<10$ $\mathrm{cfu} / \mathrm{cm}^{2}$, while $10 \mathrm{cfu} / \mathrm{cm}^{2}$ or higher levels are considered as unsatisfactory level according to the US Public Health Service for swab from ready to eat food contact surfaces (Little and Sagoo, 2009). In the present study, microbiological results were compared with the criteria used by the US Public Health Service for swab from ready to eat food contact surfaces (Little and Sagoo, 2009) and also with the criteria suggested by Dantas et al. (2006). In our study, a total of 100 beverage cans without protective cover were analyzed and 56 out of 100 cans were in satisfactory hygienic condition, containing microorganisms below $10 \mathrm{cfu} / \mathrm{cm}^{2}$ as specified in Little and Sagoo (2009). When the results are compared with the criteria suggested by Dantas et al. (2006), 95 out of 100 cans were in satisfactory hygienic condition. Average numbers of total mesophilic aerobic bacteria on the ice tea, soda, beer, fruit juice, coke samples and samples with protective cover as well as the percentages of samples with the satisfactory hygienic conditions were given in Table 1. Three of the beer and one of the ice tea samples were heavily contaminated with the numbers higher than $100 \mathrm{cfu} / \mathrm{cm}^{2}$.

Aerobic mesophilic bacteria counts of beverage cans obtained from supermarkets, grocery stores and restaurants were not significantly different $(P>0.05)$ and the percentage of samples containing unacceptable levels of TAMB according to Little and Sagoo (2009) were $49 \%, 40 \%$ and $43 \%$ among the samples tested, respectively (Table 2). Detecting a high percentage of microorganisms indicates that environmental contamination (water, earth, air etc.) is in significant 
sizes. It was thought that the reason for microbial contamination on the top surfaces of beverage cans could be at storages, the transportation of beverage cans and intensity on enter and exit activities of goods and customers in market. Dantas et al. (2006) investigated the contamination levels of beverage cans and indicated that 83 out of $96(86.5 \%)$ of the cans analyzed presented total counts of mesophilic aerobic microorganisms lower than $50 \mathrm{cfu} / \mathrm{cm}^{2}$. In a study by Michaels et al., (2003), aerobic and anaerobic bacteria, Bacillus spp., Clostridium perfringens, coagulase-negative Staphylococcus and mold counts were investigated. Escherichia coli, Salmonella spp., coagulase-positive Staphylococcus and yeast counts were recorded as non-detectable level ( $<20 \mathrm{cfu} / \mathrm{can})$. The average number of microorganisms listed for food and beverage cans revealed high contamination levels of 5.30 $\log \mathrm{cfu} / \mathrm{can}$ top surface area for bacterial counts and 5.84 cfu/ can top surface area mold spore counts. Major importance in these findings (on food and beverage cans) was the identification of Bacillus cereus and Clostridium perfringens, organisms very capable of causing foodborne illness was reported. Dantas et al., (2006) also observed that Clostridium perfringens were detected in 3 of 20 cans analyzed. Ayçiçek and Küçükkaraarslan, (2003) reported that they were obtained 127 isolates from beverage cans. The dominant microflora was Bacillus spp. (68 isolates); molds (21 isolates) and E. coli (10 isolates) were also isolated.
Total aerobic mesophilic bacteria count of beverage cans with protective cover are given in Figure 6 . The numbers were between $<0.43-1.12 \times 10^{1} \mathrm{cfu} / \mathrm{cm}^{2}$. It was observed that $25 \%$ of cans with protective cover have no growth and $95 \%$ of the samples were in satisfactory hygienic condition according to Little and Sagoo (2009). Only one of them was slightly higher than the recommended limit which is $11 \mathrm{cfu} / \mathrm{cm}^{2}$. In our study, the microbial load on all beverage cans without protective cover was detected in each of them. There is a statistically significant difference between microbiological profiles of beverage cans with and without protective cover was obtained $(\mathrm{P}<0.05)$. In the conducted analysis with beverage cans with protective cover, it was observed that microbial contamination is reduced to minimum levels. Effectiveness and necessity of using protective cover on the top surface beverage cans was proved. Different solutions are being developed by various domestic and foreign companies for the prevention of contaminations. Both producers and consumers who realize the dangers that would arise from the top surface of beverage cans offer solutions and demand. Beverages in cans are consumed directly from the cans and, in this case, the can surface enters into direct contact with the consumer's mouth. As the infectious dose can be as low as 10 microorganisms for some of the pathogens, this contact may give damage to health.

Table 1 Total aerobic mesophilic bacteria count of beverage cans with and without protective cover and percentages of cans with satisfactory hygienic levels

\begin{tabular}{l|cccc}
\hline \multirow{2}{*}{\begin{tabular}{c} 
Beverage types \\
\cline { 2 - 4 }
\end{tabular}} & \multicolumn{2}{|c}{$\begin{array}{c}\text { Total aerobic mesophilic bacteria count } \\
\left(\mathrm{cfu} / \mathrm{cm}^{2}\right)\end{array}$} & $\begin{array}{c}\text { Percentages of cans with satisfactory } \\
\text { levels of TAMB according to; }\end{array}$ \\
\cline { 2 - 5 } & Range & Average & $\begin{array}{c}\text { Little and Sagoo, } \\
(2009)\end{array}$ & $\begin{array}{c}\text { Dantas et al. } \\
(2006)\end{array}$ \\
\hline Icetea & $1.96-150.87^{\mathrm{a}}$ & $18.34(32.72)$ & 50 & 95 \\
Soda & $0.43-48.48^{\mathrm{a}}$ & $9.84(13.92)$ & 70 & 100 \\
Beer & $2.39-2173.91^{\mathrm{a}}$ & $130.14(472.19)$ & 50 & 85 \\
Fruit Juice & $0.87-77.39^{\mathrm{a}}$ & $14.08(17.84)$ & 55 & 95 \\
Coke & $0.52-26.74^{\mathrm{a}}$ & $8.42(7.56)$ & 65 & 100 \\
Samples with protective cover & $<0.43-11.18^{\mathrm{b}}$ & $2.22(2.89)$ & 95 & 100 \\
\hline
\end{tabular}

Values on the same column followed by the same letter are not significantly different $(\mathrm{P}>0.05)$. Standart deviations are given in parenthesis.

Table 2 Total aerobic mesophilic bacteria counts of beverage cans obtained from three different places

\begin{tabular}{l|ccc}
\hline \multirow{2}{*}{ Beverage types } & \multicolumn{3}{|c}{ Average numbers of total aerobic mesophilic bacteria on beverage can surfaces $\left(\mathrm{cfu} / \mathrm{cm}^{2}\right)$} \\
\cline { 2 - 4 } & Supermarket & Grocery stores & Restaurants \\
\hline Icetea & $20.84(36.17)^{\mathrm{a}}$ & $8.68(0)^{\mathrm{a}}$ & $10.22(10.22)^{\mathrm{a}}$ \\
Soda & $8.69(6.84)^{\mathrm{a}}$ & $2.91(3.30)^{\mathrm{a}}$ & $16.10(21.66)^{\mathrm{a}}$ \\
Beer & $436.39(946.51)^{\mathrm{a}}$ & $25.25(36.44)^{\mathrm{a}}$ & - \\
Fruit Juice & $6.52(5.56)^{\mathrm{a}}$ & $15.10(20.48)^{\mathrm{a}}$ & $16.23(15.81)^{\mathrm{a}}$ \\
Coke & $7.45(6.81)^{\mathrm{a}}$ & $1.73(7.08)^{\mathrm{a}}$ & $11.29(8.75)^{\mathrm{a}}$ \\
\hline \multicolumn{2}{l}{ Values on the same row followed by the same letter are not significantly different $(\mathrm{p}>0.05)$. Standart deviations are given in parenthe }
\end{tabular}

Values on the same row followed by the same letter are not significantly different $(\mathrm{p}>0.05)$. Standart deviations are given in parenthesis.

Table 3 Survival of E.coli on beverage can surfaces

\begin{tabular}{l|cc}
\hline \multirow{2}{*}{ Storage Time (day) } & The numbers of E.coli on beverage can $\left(\log \mathrm{cfu} / \mathrm{cm}^{2}\right)$ \\
\cline { 2 - 3 } & $4^{\circ} \mathrm{C}$ & $25^{\circ} \mathrm{C}$ \\
\hline 0 & $3.91(0.25)$ & $3.91(0.25)$ \\
20 & $0.92(0.27)$ & $2.07(0.60)$ \\
30 & $-*$ & $-*$ \\
\hline
\end{tabular}

*Results are below the detection limit of $0.43 \mathrm{cfu} / \mathrm{cm}^{2}$. 


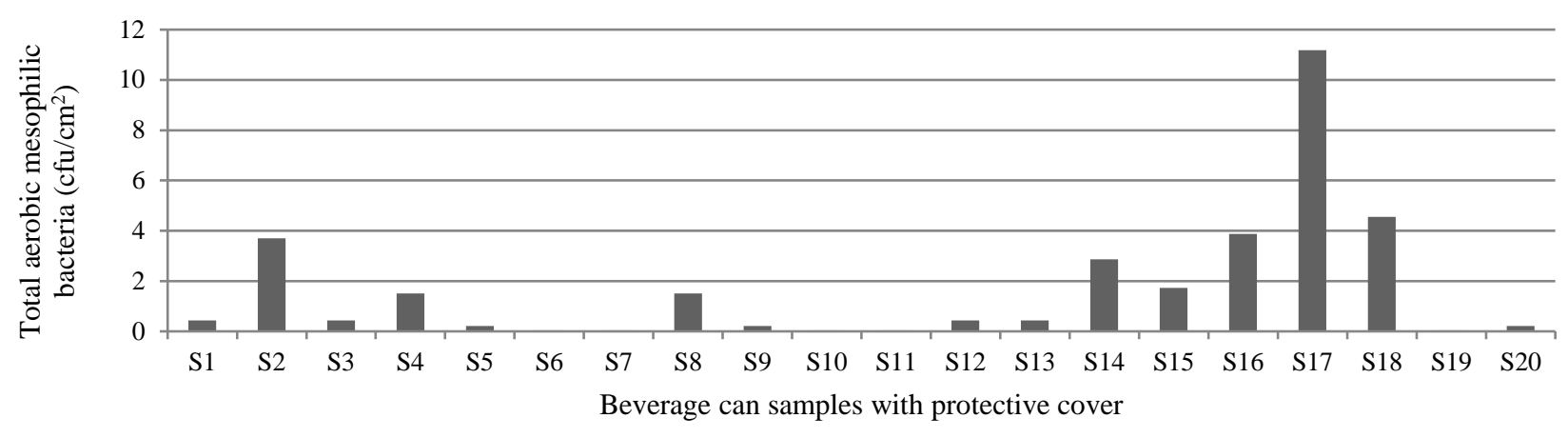

Figure 6 Total aerobic mesophilic bacteria counts of can top surfaces with protective cover $\left(\mathrm{cfu} / \mathrm{cm}^{2}\right)$

After filling operation of beverage cans, the protection of packaging should be considered during transportation to points of sale to prevent contamination on the top surfaces of beverage cans. When beverage cans removed from their shrink packaging at the points of sale, the contact between outer surface of packaging with the top surfaces of beverage cans should not be allowed. Beverage cans should be placed on clean shelves with clean hands (Ayçiçek and Küçükkaraarslan, 2003). Top surfaces of beverage cans at shelves could be exposed to contamination through ambient air, consumers, dirty shelves, staff and insects. For this reason, at the places like market, grocery and restaurant, the important care measures must be taken on environment and personal hygiene and to struggle with pests and rodents (Ayçiçek and Küçükkaraarslan, 2003). In the present study, mold growth was observed on the external top surfaces of can at the refrigerator on the shelf during the collection of samples for two different places. Although, it is not very common to come across such visibly moldy cans, at rare circumstances, it is still possible to see them on shelves. Another dimension of the issue is, the staff could detect and rub the surface and make the moldy surface imperceptible to the customer, keeping it on the shelf for consumption and the customers could be at risk by consuming these products.

The presence of coliform was found just in one sample among 50 samples analyzed and total coliform bacteria count was determined as $0.17 \mathrm{MPN} / \mathrm{cm}^{2}$ (4 MPN/can top surface area). Faecal coliform bacteria and E.coli was not detected on the analyzed samples. In the present study, the hygienic statuses of beverage cans were determined by using TAMB, coliform and E.coli count results as indicator microorganisms that widely used to assess the efficacy of sanitation programmes. Microbial indicators are a microorganism or group of microorganisms that is indicative of the possible presence of pathogens and the detection and enumeration of indicator organisms and whose presence in given numbers points to inadequate processing for safety (Lues and Tonder, 2007).

Survival of $E$. coli inoculated on the top surface of cans at the $0^{\text {th }}, 10^{\text {th }}, 20^{\text {th }}$ and $30^{\text {th }}$ days of storage at $4^{\circ} \mathrm{C}$ and $25^{\circ} \mathrm{C}$ were given in the Table 3. E. coli counts were below the detection limit $\left(0.43 \log \mathrm{cfu} / \mathrm{cm}^{2}\right)$ at 20 and 30 days of storage regardless of storage temperatures. It was detected that $E$. coli inoculated on the top surfaces of beverage cans survive at least 10 days, while the number of E. coli was below the detection limit on $20^{\text {th }}$ and $30^{\text {th }}$ days of storage. Kusumaningrum et al. (2003) also suggested that pathogens remain viable on dry stainless steel surfaces and present a contamination hazard for considerable periods of time depending on the contamination levels and type of pathogen. If microorganisms remain on a given surface for a relatively long time, they can multiply and, eventually, form biofilms (Uhlich et al., 2006). Packaging materials supply a means to preserve, protect, market and distribute foods, on the other hand in this study demonstrated that the surface of beverage cans could be contaminated by the microorganisms.

\section{Conclusions}

For most of the people, microbial profile of top surfaces of beverage cans is very important because it is a product consumed by direct mouth contact with the top surface. As a result of analyses on the top surfaces of beverage cans sold as uncovered top surface, it was observed that there are serious contaminations. Since microorganisms can not seen with naked eyes while buying beverage cans, it is not possible to get an idea about their microbial profile. Even on top surfaces that appear very clean, extremely dangerous levels of contamination could be found. Considering all these situations and comparing the results of analysis of beverage cans sold as uncovered top surfaces and beverage cans which are covered with aluminium foil on the top surface, it was proved that covering top surfaces of beverage cans with a material is an applicable, useful and protective method.

According to the results obtained by the microbiological analysis of samples, it is concluded that the microbiological contamination levels of beverage cans are not the same and external surfaces of beverage cans might be potential risk for human health. As a result, the top surfaces of beverage cans pose a risk to health of consumers and some technologies used to protect the top surfaces of cans against external contamination is suggested to prevent contamination.

\section{References}

Ayçiçek H and Küçükkaraarslan A. 2003. Metal Meşrubat Kutu D1ş Yüzeylerinin Mikrobiyel Profili. Yüzüncü Y1l Üniversitesi Veteriner Fakültesi Dergisi., 14: 118-123. 
BAM. 2001. Bacteriological Analytical Manual, Aerobic Plate Count. Bacteriological Analytical Manual (8th ed.) Revision A. Ch. 3.

BAM. 2002. Bacteriological Analytical Manual, Enumeration of Escherichia coli and the Coliform Bacteria. Bacteriological Analytical Manual (8th ed.) Revision A. Ch. 4.

CFP. 2000. Conference for Food Protection, Comprehensive Guidelines for Food Recovery Programs. Developed by the Food Recovery Commitee., Council I.

EC. 2013. De Silva EP and De Martinis, Current knowledge and perspectives on biofilm formation: The case of Listeria monocytogenes. Applied Microbiology and Biotechnology., 97: 957-968. DOI: 10.1007/s00253-012-4611-1.

Daniels RW. 1991. Applying HACCP to new-generation refrigerated foods at retail beyond. Food Technology., 45: $122-4$.

Dantas ST, da Silva N, Dantas FBH. 2006. External microbiological contamination of beverage packaging. Brazilian Journal of Food Technology., 9: 193-199.

Devi S, Murray CJ. 1991. Cockroaches (Biatta and Periplanetta species) as reservoirs of drug-resistant Salmonellas. Epidemiological Inflection., 107: 357-361. PMID: 1936157.

Giauris ED, Nychas GJE. 2006. The adherence of Salmonella Enteritidis PT4 to stainless steel: the importance of the aireliquid interface and nutrient availability. Food Microbiology., 23: 747-752. PMID: 16943077; DOI: 10.1016/j.fm.2006.02.006

Jiang XP, Doyle MP. 1999. Fate of Escherichia coli O157:H7 and Salmonella enteritidis on currency. Journal of Food Protection., 62: 805-807. PMID: 10419277.

Kass HP, Riemann PH. 2006. Foodborne Infections and Intoxications. 3rd Edition. Food Science and Technology International Series. Elsiver. pp. 3-5. ISBN: 9780080454115

Kuda T, Yano T, Kuda MT. 2008. Resistances to benzalkonium chloride of bacteria dried with food elements on stainless steel surface. LWT-Food Science and Technology., 41: 988993. DOI: $10.1016 /$ j.lwt.2007.06.016

Kuda T, Iwase T, Chaturongkasumrit Y, Takahashi H, Koyanagi T, Kimura B. 2011. Surfactant-disinfectant resistance of Salmonella and Staphylococcus adhered and dried on surfaces with egg compounds. Food Microbiology., 28: 920925. PMID: 21569934; DOI:10.1016/j.fm.2010.12.006.

Kuda T, Iwase T, Chaturongkasumrit Y, Takahashi H, Koyanagi T, Kimura B. 2012. Resistances to UV-C irradiation of Salmonella Typhimurium and Staphylococcus aureus in wet and dried suspensions on surface with egg residues. Food Control., 23: 485-490. DOI: 10.1016/j.foodcont. 2011.08.018.

Kuda T, Shibata G, Takahashi H, Kimura B. 2015. Effect of quantity of food residues on resistance to dessication of food-related pathogens adhered to a stainless steel surface. Food Microbiology, 46: 234-238. PMID: 25475291; DOI: 10.1016/j.fm.2014.08.014.
Kusumaningrum HD, Van Putten MM, Rombouts FM, Beumer RR. 2002. Effects of antibacterial dishwashing liquid on foodborne pathogens and competitive microorganisms in kitchen sponges. Journal of Food Protection., 65: 61-65. PMID: 11811157.

Kusumaningrum HD, Riboldi G, Hazeleger WC, Beumer RR. 2003. Survival of foodborne pathogens on stainless steel surfaces and cross-contamination to foods. International Journal of Food Microbiology., 85: 227 - 236. PMID: 12878381 .

Li R, Kuda T, Yano T. 2014. Effect of food residues on efficiency of surfactant disinfectants against food related pathogens adhered on polystyrene and ceramic surfaces. LWT-Food Science and Technology., 57: 200-206. DOI: 10.1016/j.lwt.2013.11.018.

Little C, Sagoo S. 2009. Evaluation of the hygiene of ready-toeat food preparation areas and practices in mobile food vendors in the UK. International Journal of Environmental Health Research., 19: 431-443. DOI: 10.1080/09603120903079364.

Lues JFR, Van Tonder I. 2007. The occurrence of indicator bacteria on hands and aprons of food handlers in the delicatessen sections of a retail group. Food Control, 18(4): 326-332. DOI: 10.1016/j.foodcont.2005.10.010.

Michaels B, Ganger V, Schultz A, Curiale MS. 2003. A microbial survey of food service can openers food and beverage can tops and cleaning methodology effectiveness. Food Service Technology., 3: 123-132. DOI: 10.1111/j.1471-5740.2003.00072.x.

Reij MW, den Aantrekker WD. 2004. ILSI Europe Risk Analysis in Microbiology Task Force. Recontamination as a source of pathogens in process foods. International Journal of Food Microbiology., 91: 1-11. DOI: 10.1016/S01681605(03)00295-2.

Scott E, Bloomfield SF. 1990. The survival and transfer of microbial-contamination via cloths. hands and utensils. Journal of Applied Bacteriology., 68: 271-278. PMID: 2111304.

Simoes M, Simoes LC, Vieirab MJ. 2010. A review of current and emergent biofilm control strategies. LWT-Food Science and Technology., 43: 573-583. DOI: 10.1016/j.lwt.2009. 12.008 .

Uhlich GA, Cooke PH, Solomon EB. 2006. Analyses of the reddry-rough phenotype of an Escherichia coli O157: H7 strain and its role in biofilm formation and resistance to antibacterial agents. Applied and Environmental Microbiology., 72(4): 2564-2572. DOI: 10.1128/AEM. 72.4.2564-2572.2006.

US Navy. 2003. Virtual Naval Hospital. Manual of Naval Preventive Medicine. Department of the Navy. Bureau of Medicine and Surgery. http://www.VNH.org/Preventive Medicine/Chapter1/Section3.html [07.06.2016]

Valero A, Ortiz JC, Fongaro G, Hernandez M. 2017. Definition of sampling producers for collective-eating establishments based on the distribution of environmental microbiological contamination on food handlers, utensils and surface. Food Control., 77: 8-16. DOI: 10.1016/j.foodcont.2017.01.013. 